\title{
大都市圏の河川とその周辺域における越冬期の鳥類に影響する環境要因
}

\section{Environmental Factors Influencing Wintering Birds in Metropolitan Riparian Area and its Surroundings.}

高林 裕* 福井 亘* 宮本 脩詩*

\author{
Yutaka TAKABAYASHI Wataru FUKUI Shushi MIYAMOTO
}

\begin{abstract}
Biodiversity conservation in urban areas is one of the key task for landscape and urban planning. The concept of 'compact city' provides new possibilities for creating open spaces which can be habitats for many species in urban areas. The purpose of this study is to clarify the environmental factors influencing populations of wintering birds in metropolitan riparian area and its surroundings to obtain useful guidelines for enhancing urban biodiversity. We surveyed populations of birds and land covers along the river called Okawa in Osaka prefecture in winter 2016. To find the environmental factors influencing populations of birds, we used the Generalized Liner Mixed Model (GLMM). As a result, Passer montanus, Columba livia, Hypsipetes amaurotis, Spodiopsar cineraceus, Turdus naumanni, and Motacilla alba adapted to the metropolitan riparian area. Through this study, we got two results for urban biodiversity. 1) The presence of high trees, non-pavement open spaces, curved water edge and concrete banks along the river, influenced some bird's populations with the distance from the nearest other rivers or forests. 2) Though a lot of species avoided buildings or pavement open spaces, some species like Corvus macrorhynchos, Phoenicurus auroreus and Motacilla alba, used these areas.
\end{abstract}

Keywords: urban biodiversity, metropolis, riparian area, green network, birds, environmental factors キーワード：都市の生物多様性, 大都市圏, 河川, 水と緑のネットワーク, 鳥類, 環境要因

\section{1. 研究の背景}

近年, 都市の生物多様性が重要視されている。これは都市域の 拡大による生物の生息域の分断・孤立を防ぎ，人々が身近な空間 で生物之触れ合える利点がある 1)。人々が生活する都市に生物生 息空間を形成する際に，今後の都市計画と整合性を図った緑地計 画の視点が必要だと考えられる。日本の総人口は, 2015 年度は 1 億 2,709 万人であったが, 2040 年に 1 億 1,092 万人になり,さ

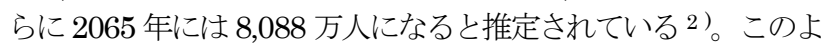
うな人口減少を受けた今後の都市計画として，都市機能を多極的 に集約化し，それらを公共交通でつなぐ多極ネットワーク型のコ ンパクトシティの形成が, 2050 年までの指針とされている3)。今 後集約化が進むであろう都市において，生物多様性を確保寸る緑 地計画を推進させるためには，ケーススタディとして人口密度が 高く建築物が密集する景観の生物多様性に関する知見の蓄積が必 要だと考えられる。前述した特徵を有する大都市圏に目を転じる と，人口密度の高さや建築物の密集，網の目のような道路網など の諸要素が見られ, 都市インフラについて考慮す心゙き要素は多い。 その要素のひとつである都市の河川について見ると，都市の河川 は緑地や水辺空閒などを生態的回廊でつなぐ「水と緑のネットワ 一ク」を形成する際の軸として捉えられており 1)，今後の都市の 生物多様性を考えるうえで重要な緑地だと考えられた。以上の背 景を受けて, 本研究では大都市圈の河川の生物多様性に着目した。

本研究では，生物多様性の指標として知見の蓄積が多い鳥類を 研究対象とした。河川や水辺空間の鳥類に関寸る既往研究から, 砂碩地 4-6)や砂碩地から河畔林までの自然被覆要素, 水際から堤防 法面までの公配 7)，陸域と水域の間のコンクリートによる緩衝帯 8)などが主に水上で生息する水鳥の出現に影響すると報告されて いる。また川幅 ${ }^{4}$ や高茎草地の面積 ${ }^{9)}$, 自然植生要素の数 ${ }^{10)}$, 建 築物や樹木，芝生の面積 ${ }^{8}$, 造成地の有無や騒音, 交通量の大小 11), 周辺河川までの距離, 空間の開放度, 草地の面積 12)などが水 鳥以外の陸域で生息する鳥類の出現にも影響すると報告されてい
る。さらに, 都市の緑地の鳥類に影響する環境要因として, 緑地 の面積 13,14)や植生構造の複雑さ, 下層植生の有無 ${ }^{15-17)}$, 緑道の連 結 ${ }^{18-20)}$ ，建築物や舗装地の面積 21,22)などが報告されている。しか し, 建築物が密集する大都市圈の河川における鳥類に関する研究 は, 周辺環境を加味しない, 水際付近の限定された範囲内での研 究8)はみられるが，未だ少ない現状にある。

よって本研究では大都市圈の河川における鳥類の出現傾向と広 域的な周辺環境を含む土地被覆との関係性の把握を行ない，今後 集約化が進むであろう都市の生物多様性向上に寄与寸る緑地計画 の基礎的な知見を得ることを研究の目的とした。

\section{2. 研究方法}

(1) 研究対象地

推計人口 $2,702,033$ 人, 人口密度が $1 \mathrm{~km}^{2}$ あたり 11,998 人の大 阪市 23$)$ を建築物の密集する大都市圈の一例として選定し, 大阪市 を流れる大川の沿道空間を研究対象地とした（図一-1)。大川は一 級河川に指定された淀川の支流のひとつである。北側に淀川，南 東に大阪城公園が位置し，東と西には住宅地が，南西には中之島

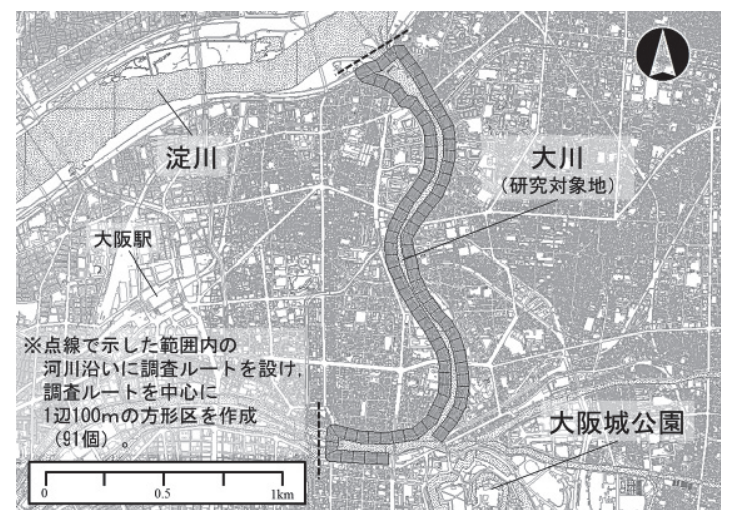

図-1 研究対象地

*京都府立大学大学院生命環境科学研究科 
を中心とした商業地域が広がる。河岸は陸域と水域を分断する矢 板護岸であり，抽水植物等の自然植生の群落はほとんどみられな い24）。しかし，毛馬桜ノ宮公園を始めとした植栽により緑の少な い大阪市において市民の生活環境にうるおいを与える緑の保存と 整備が図られた空間である25)

\section{(2) 研究対象空間の設定}

鳥類調査の調査ルートと，対象空間を連続して分割する方形区 を基盤地図情報 2,500（国土地理院）をもとに地理情報システム （以下，GIS）を用いて作成した。調査ルートは東岸と西岸を一 度の調查で踏査できるように設定し，踏查が困難であった箇所は 研究対象空間から除外した。方形区は既往研究 8,18)を参考に，調 査ルートを中心にして 1 辺 $100 \mathrm{~m}$ として連続的に発生させたとこ ろ, 合計 91 個作成された。鳥類調査と植栽調査のデータは全て この 91 個の方形区内に入力され，解析の単位として用いた。使 用した GIS のソフトウェアはArc Map 10.5 (ESRI 社) である。

\section{(3) 鳥類調査}

鳥類は越冬期（12 月から 3 月ごろ）の方が繁殖期（4月から 6 月ごろ）よりも出現種数が多く 26,27), 都市の小規模緑地では繁殖 期の鳥相が貧弱になる 28)。また大都市圏の河川空間において繁殖

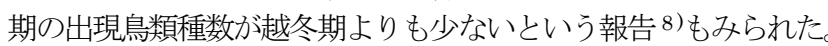
以上を踏まえて，種数が豊富と考えられる越冬期を研究対象とし て鳥類調査を行なった。鳥類調査は 2016 年 2 月の晴れまたは曇 りの日の午前 7 時から 11 時の間に, 週 2 回を目安に計 8 回実施 した。調査方法はラインセンサス法 ${ }^{29)}$ を用い，調査ルート沿いに 歩きながら半径 $50 \mathrm{~m}$ 圈内に出現した鳥類を目視または声で種を 判別し，1/1,500の縮尺の地図を印刷した調查用紙に直接記録し た。調査時間のずれや調査の偏りを考慮して，1 度置きにルート を周回する方向を逆転させた。鳥類調査のデータは GIS 上で作成 した方形区の中にポイントデータとして全て入力・集計した。

\section{（4）植栽調査およひ環境要因の設定}

各既往研究の知見 $4-22$ ) と, 水生植物や高茎草本等が確認されな かった研究対象地の特性を踏まえて，鳥類に影響を与えると考え られる環境要因を以下の通り設定した。

\section{1）方形区内の土地被覆}

2015 年の 12 月に周辺の土地被覆の予備調査を現地にて実施し, 2016 年 11 月から 2017 年 1 月の間に，方形区周辺の土地被覆を 現地にて踏査した。予備調査で確認された土地被覆と大幅に変化 している箇所は確認されなかった。植栽面積のデータを得るため に目視で樹木の高さや常緑・落葉の違い等を観測し，1/1,500の 縮尺の地図を印刷した調査用紙に植栽場所と概形をそれぞれ直接 記録した。本研究て観測・設定した土地被覆を表一1にまとめた。

樹木は観測の際に常緑樹高木 (8m 以上), 常緑樹亜高木 (2〜 $8 \mathrm{~m})$ 常緑樹低木 $(0.5 ２ \mathrm{~m})$ と落葉樹高木, 落葉樹亜高木, 落葉 樹低木に区分した。また，アスファルトによる舗装が無く，グラ ウンドとして使用されていない非舗装地を草本が生育できる空間 とした。さらに建築物と舗装地(道路や広場など), 開放水域に加 えて, 水域と陸域が分断されていないコンクリート等で被覆され た空間 (緩衝帯) や，水際の陸地に草本が生育する余地のある空 間として緩衝帯の水涯線沿いの半径 $2 \mathrm{~m}$ 圏内に存在する非舗装地 (水際植生) を設定した。加えて, 方形区内の水際線の長さを水 際部分の湾曲の指標とした。現地調査で得られたこれらのデータ は, GIS 上で国土地理院の基盤地図情報 2,500 や衛星画像 (SPOT7 号撮影, 2015 年 12 月 30 日, 分解能約 $1.5 \mathrm{~m}$ ) を補助 的に照合しつつ, 方形区内にポリゴンデータとして抽出・作成し た。以上得られた全てのポリゴンデータを用いて, 91 個の方形区 内に占める面積割合としてそれぞれ算出し，これらを方形区内の 土地被覆とした。

2）方形区周辺の環境条件 表-1＼cjkstart方形区内の土地被覆と方形区周辺の環境条件

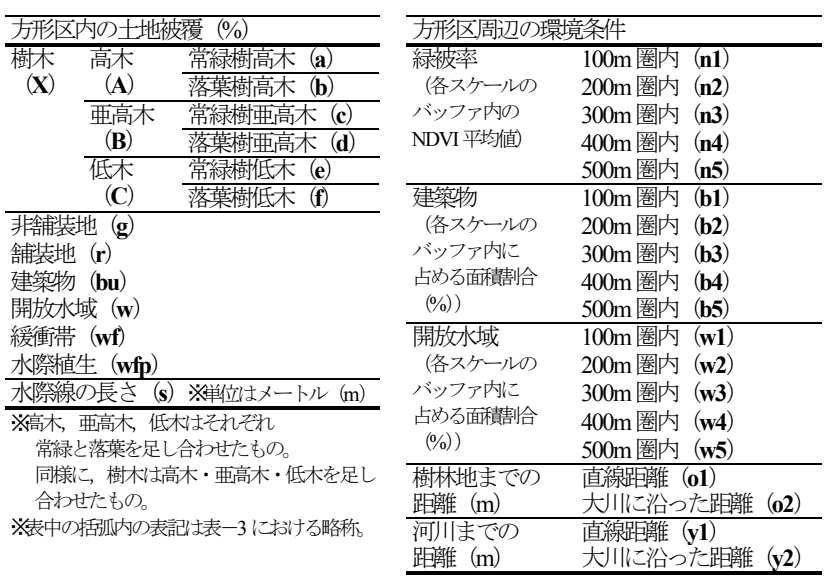

方形区周辺の環境条件を表一 1 にまとめた。正規化差植生指数 (以下, NDVI) を衛星画像により算出し, 緑被率の指標とした。 91 個の方形区の中心から, 半径 $100 \mathrm{~m}, 200 \mathrm{~m}, 300 \mathrm{~m}, 400 \mathrm{~m}$, $500 \mathrm{~m}$ のバッファをそれぞれ発生させ, 各バッファ内の NDVI の 平均值と, 建築物, 開放水域の面積割合を GIS 上でそれぞれ算出 した。本研究では調査地周辺の鳥類生息地として, 淀川 (周辺の 河川）と大阪城公園 30）(周辺の樹林地）に着目し，方形区の重心 からの最短距離と，大川に沿った距離をそれぞれ算出した。

\section{（5）データ解析}

鳥類の種ごとの出現傾向と環境条件との関係を把握寸るために, 本研究では一般化線形混合モデル (Generalized Linear Mixed Model, 以下, GLMM) を用いた。GLMM は応答変数と説明変 数との関係を求める際に，観測データにばらつきをもたらす観測 不可能な要因をランダム効果としてモデルに組み込むことが可能

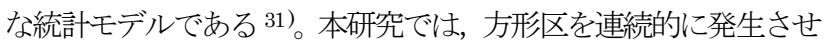
たことによって生じるそれぞれの位置関係などの場所差を加味し て，91個の方形区に対してランダム効果を適用させた。応答変数 には出現頻度が $33 \%$ 以上種は種ごとの個体数（8回の調査の合 計）を用いてポアソン分布を仮定し，出現頻度が $33 \%$ 未満の種は 0，1の在不在データに変換した後に，二項分布を仮定した。説明 変数には表-1 に示した方形区内の土地被覆と方形区周辺の環境 条件を設定した。なお，各面積割合に対しては逆正弦変換を行な い，各距離と NDVI に対しては対数変換を行なった。

GLMM に投入する説明変数は，100～500m 圈内の NDVI ・ 建 築物などスケールによる解像度が異なる変数や, 相関が高い変数 の組み合わせを同時にモデルに組み込むことを避けたうえで，す べての変数について総当たりで解析を行なった。モデル選択の結 果, 個体数と有意な関係性を示寸説明変数を含み, なおかつ $\mathrm{AIC}$

(Akaike's Information Criterion) の最も小さいモデルをベスト モデルとして採用した。GLMM は R version 3.4.1（2017 The R Foundation for Statistical Computing）を用い, 総当たりの変数 選択はR のパッケージMuMInの dredge 関数を補助的に用いた。 また, 各変数変換はエクセル統計 2012 (株式会社社会情報サ一ビ ス）をそれぞれ使用した。

\section{3. 結果と考察}

\section{(1) 鳥類調査結果の概要}

鳥類調査の結果を表一 2 に示した。確認されたすべての鳥類は 9 目 20 科 35 種 6,816 羽であった。スズメやドバト，ヒヨドリ， ムクドリ，ツグミ等の都市の小規模緑地や住宅地でも多く出現す る種 ${ }^{32,33)}$ の出現頻度が高く, これらの種は大都市圈の河川を幅広 く利用していると推察された。対照的に, マガモやカルガモ, ヒ ドリガモ，ホシハジロ，キンクロハジロ等の水鳥は，総個体数は 


\section{表－2 鳥類調査結果}

\begin{tabular}{|c|c|c|c|c|c|}
\hline 出現厅形风数が10 & 地点以上O乐 & & 出覞厅形数が 10 & 地点末満 & \\
\hline 種名 & $\begin{array}{l}\text { 総固休数 } \\
\text { 时 }\end{array}$ & 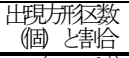 & 種名 & $\begin{array}{c}\text { 総固休数 } \\
\text { 时 }\end{array}$ & 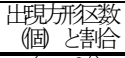 \\
\hline マガモ & 79 & $11(12.09 \%)$ & コガモ & 3 & $1(1.10 \%)$ \\
\hline カルガモ & 51 & $10(10.99 \%)$ & ヒドリガモ & 90 & $7(7.69 \%)$ \\
\hline ホシハジロ & 164 & $11(12.09 \%)$ & キンクロハジロ & 101 & $4(4.40 \%)$ \\
\hline キジバト & 63 & $15(16.48 \%)$ & カワアイサ & 6 & $4(4.40 \%)$ \\
\hline ドバト & 961 & $76(83.52 \%)$ & アオサギ & 14 & $2(2.20 \%)$ \\
\hline カワウ & 130 & $36(39.56 \%)$ & コサギ & 9 & $1(1.10 \%)$ \\
\hline オオバン & 187 & $29(31.87 \%)$ & ケリ & 3 & $1(1.10 \%)$ \\
\hline ユリカモメ & 418 & $27(29.67 \%)$ & シロチドリ & 2 & $1(1.10 \%)$ \\
\hline モズ & 46 & $18(19.78 \%)$ & カモメ & 24 & $4(4.40 \%)$ \\
\hline ハシボソガラス & 164 & $42(46.15 \%)$ & カワセミ & 3 & $1(1.10 \%)$ \\
\hline ハシブトガラス & 335 & $44(48.35 \%)$ & コゲラ & 15 & $4(4.40 \%)$ \\
\hline シジュウカラ & 126 & $25(27.47 \%)$ & ウグイス & 18 & $2(2.20 \%)$ \\
\hline ヒヨドリ & 759 & $75(82.42 \%)$ & イソヒヨドリ & 3 & $2(2.20 \%$ \\
\hline メジロ & 84 & $30 \quad(32.97 \%)$ & セグロセキレイ & 23 & $2(2.20 \%)$ \\
\hline ムクドリ & 442 & $66(72.53 \%)$ & カワラヒワ & 5 & $3(3.30 \%)$ \\
\hline シロ八ラ & 72 & $24(26.37 \%)$ & ※表中の割合は, & 方形区数 & 1 個）に占める \\
\hline & 416 & $54(59.34 \%)$ & 各種の出現した & 形区数の害 & \\
\hline ジョウビタキ & 43 & $11 \quad(12.09 \%)$ & & & \\
\hline $\begin{array}{l}\text { スズメ } \\
\text { ハクセキレイ }\end{array}$ & $\begin{array}{l}1,628 \\
329\end{array}$ & $\begin{array}{ll}88 & (96.70 \%) \\
54 & (59.34 \%)\end{array}$ & & & \\
\hline 20 & & $34(39.24 / 0)$ & & & \\
\hline
\end{tabular}

多く出現頻度は低い傾向を示し，特定の空間への選好性がうかが えた。また，カワセミやコゲラ，イソヒヨドリなどの種も少数な がら確認された。GLMM のモデル選択の結果, 個体数と有意な 関係性を示す説明変数を含むべ゙ストモデルが得られた種とその推 定結果を表一 3 に示した。鳥類の種ごとに得られた結果は異なり， 以下に各環境要因に着目して結果を取り上げた。

\section{（2）緑地と鳥類の個体数との関係}

植生構造が鳥類の出現種数に影響を与えるという報告 15-17)が みられるが，本研究では樹木の高さや常緑・落葉の違いが特に出 現頻度が高い種の個体数や出現の有無と有意な関係性を示した。 具体的には，スズメ（常緑樹低木：正，常緑樹高木・落葉樹低木： 負)とドバト (常緑樹高木: 正, 常緑樹亜高木: 負)，ヒヨドリ (常 緑樹高木・常緑樹亜高木・落葉樹亜高木 : 正)，ムクドリ（樹木： 正)，ハシブトガラス (常緑樹高木 : 正)，ハシボソガラス (常緑 樹高木・常緑樹亜高木 : 正，落葉樹低木 : 負), カワウ (常緑樹亜 高木: 負), メジロ (落葉樹高木: 正), シジュウカラ (高木: 正), シロ八ラ（樹木 : 正）などの種である。メジロは本研究では落葉 樹高木に加えて $100 \mathrm{~m}$ 圈内の開放水域の面積割合とも有意な正の 関係性を示した。メジロは都市の緑地では常緑広葉樹林を選好す ると報告されているが 15), 大都市圈の河川では周辺の視認性が高 い空間を選好することが示唆された。また，草本の生育環境であ る非舗装地の面積割合がツグミやハクセキレイ，カルガモなど地 上付近で採食する種 ${ }^{34)}$ の個体数と有意な正の関係性を示した。

方形区内の植栽に加えて, 開放水域の面積割合がドバト $(100 \mathrm{~m}$ 圈内 : 正) やスズメ $(100 \mathrm{~m}$ 圏内 : 負)，ヒヨドリ $(400 \mathrm{~m}$ 圈内 : 負）の個体数と有意な関係性を示し，周辺の緑被率がハシブトガ
ラス (400m 圈内 : 正) やハシボソガラス（100m 圈内 : 正）の 個体数と有意な関係性を示した。スズメやヒヨドリは開放的な空 間を避け，ドバトは開放的な空間を選好する傾向にあること，八 シブトガラスとハシボソガラスは方形区内の植栽と併せて広範囲 の緑被率が高、空間を選好すると推察された。加えて，開放的な 空間の地上で採餌する ${ }^{34)}$ ムクドリとハシボソガラス, ツグミが周 辺の河川（淀川）に近い空間を選好した。また，樹上で昆虫を捕

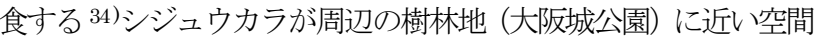
を選好する結果が得られた。以上のことから，大都市圈の河川に おける鳥類出現は，河川沿いの植栽に加えて広域的な緑被率や周 辺の緑地（河川や樹林地）との近接性が影響すると考えられた。

\section{（3）水際や水域と鳥類の個体数との関係}

都市の河川における既往研究 4,8,9) と同様に，方形区内の開放水 域や緩衝帯，水際植生の面積割合，水際線の長さといった水域付 近の土地被覆は主に水上や水辺で生息する鳥類の個体数や出現の 有無と有意な正の関係性を示した。具体的には八クセキレイ（開 放水域 : 正) や力ワウ (水際線の長さ : 正)，オオバン (水際線の 長さ・水際植生: 出現), ユリカモメ (開放水域・水際植生:出現), マガモ（水際線の長さ・緩衝帯 : 出現)，ホシハジロ (開放水域 : 出現)，カルガモ (水際線の長さ : 出現) 等の種である。

一方，方形区周辺の緑被率がユリカモメやカルガモ（100m 圈 内), マガモ (500m 圈内) の出現と有意な負の関係性を示し，方 形区周辺の開放水域の面積割合がカワウ（300m 圈内）の個体数 やオオバン (200m 圈内) の出現と有意な負の関係性を示した。 大都市圈の河川ではこれらの種は開放的な空間を避けて水際周辺 の空間に出現することが示唆された。また，水際線の長さは陸域 に生息するスズメやハシブトガラス，ハシボソガラスの個体数と も有意な正の関係性を示した。オオバンとマガモ，ホシハジロが 河川 (淀川) に近い空間を，ハクセキレイとカルガモが樹林地 (大 阪城公園）に近い空間を選好した。以上のことから，大都市圈の 河川では周辺の緑地に近い空間における水際付近の湾曲や緩衝帯 の整備が鳥類の種多様性を確保する上で重要だと考えられた。

\section{（4）人工物と鳥類の個体数との関係}

都市における既往研究 8,11) と同様に多くの種は建築物や舗装地 などの人工物と負の関係性を示した。方形区内の舗装地の面積割 合はシロ八ラの個体数と有意な負の関係性を示し，方形区内の建 築物の面積割合はカルガモの出現と有意な負の関係性を示した。 また，方形区周辺の建築物の面積割合はドバトやムクドリ，八ク セキレイ (100m圈内)，ハシボソガラス ( $200 \mathrm{~m}$ 圈内)，ヒヨド リ（300m 圈内）の個体数と, オオバン $(100 \mathrm{~m}$ 圈内）やメジロ ( $200 \mathrm{~m}$ 圈内)，マガモ $(400 \mathrm{~m}$ 圈内) の出現と有意な負の関係性 を示した。

表-3 GLMM 結果

\begin{tabular}{|c|c|c|c|c|c|c|c|c|c|}
\hline 種名 & 出現頻度（\%) & 最尤推定值 & & & & & & 切片 & AIC \\
\hline スズメ & 96.70 & $-0.03( \pm 0.02) \mathbf{a}$ & $+0.07( \pm 0.02) \mathbf{e}$ & $-0.04( \pm 0.02) \mathbf{f}$ & $+0.22( \pm 0.12) \mathbf{s}$ & $-0.03( \pm 0.02) \mathbf{w 1}$ & & $2.43( \pm 0.75)$ & 335.50 \\
\hline ドバト & 83.52 & $0.06( \pm 0.02) \mathbf{a}$ & $-0.07( \pm 0.03) \mathbf{c}$ & $-0.04( \pm 0.02)$ bu1 & $+0.03( \pm 0.02)$ w1 & & & $1.30( \pm 0.74)$ & 312.70 \\
\hline ヒヨドリ & 82.42 & $0.05( \pm 0.02) \mathbf{a}$ & $+0.04( \pm 0.03) \mathbf{c}$ & $+0.03( \pm 0.02) \mathbf{d}$ & $-0.15( \pm 0.04)$ bu3 & $-0.10( \pm 0.04) \mathbf{w} 4$ & & $7.01( \pm 1.25)$ & 269.6 \\
\hline ムクドリ & 7253 & $0.07( \pm 0.02) \mathbf{X}$ & $-0.26( \pm 0.12) \mathbf{s}$ & $-0.06( \pm 0.02)$ bu1 & $+1.03( \pm 0.19) \mathrm{o1}$ & & & $-5.90( \pm 1.86)$ & 213.4 \\
\hline ツグミ & 5934 & $0.08( \pm 0.02) \mathbf{g}$ & $-0.62( \pm 0.27) \mathbf{y} 2$ & & & & & $2.67( \pm 2.18)$ & 238.30 \\
\hline ハクセキレイ & 5934 & $0.06( \pm 0.02) \mathbf{g}$ & $+0.06( \pm 0.02) \mathbf{r}$ & $+0.05( \pm 0.02) \mathbf{w}$ & $-0.05( \pm 0.03)$ bu1 & $-0.38( \pm 0.23)$ o1 & & $-1.18( \pm 2.63)$ & 228.10 \\
\hline ハシブトガラス & 4835 & $0.06( \pm 0.04) \mathbf{a}$ & $-0.08( \pm 0.04) \mathbf{f}$ & $+0.07( \pm 0.03) \mathbf{r}$ & $+0.74( \pm 0.42) \mathbf{s}$ & $+0.22( \pm 0.09) \mathbf{n} 4$ & $+0.22( \pm 0.07)$ bu5 & $-23.35( \pm 6.00)$ & 215.60 \\
\hline ハシボソガラス & 46.15 & $\begin{array}{l}0.10( \pm 0.03) \mathbf{a} \\
-0.11( \pm 0.05) \mathbf{b u 2}\end{array}$ & $\begin{array}{l}+0.09( \pm 0.04) \mathbf{c} \\
+0.93( \pm 0.30) \text { o1 } \\
\end{array}$ & $+0.06( \pm 0.04) \mathrm{e}$ & $-0.06( \pm 0.03) \mathbf{f}$ & $+0.50( \pm 0.24) \mathrm{s}$ & $+0.14( \pm 0.06) \mathbf{n 1}$ & $-15.49( \pm 5.51)$ & 167.30 \\
\hline カワウ & 3956 & $-0.19( \pm 0.06) \mathbf{c}$ & $+1.02( \pm 0.56) \mathbf{s}$ & $-0.14( \pm 0.06) \mathbf{w 3}$ & & & & $-1.60( \pm 2.87)$ & 159.50 \\
\hline 济 & 32.97 & $0.13( \pm 0.05) \mathbf{b}$ & $-0.09( \pm 0.06)$ bu2 2 & $+0.09( \pm 0.05) \mathbf{w 1}$ & & & & $-2.53( \pm 2.08)$ & 104.50 \\
\hline オオバ & 31.87 & $0.97( \pm 0.64) \mathbf{s}$ & $+2.22( \pm 35.24) \mathrm{wfp}$ & $-0.11( \pm 0.05)$ bu1 & $-0.47( \pm 0.22) \mathbf{w} 2$ & $+1.54( \pm 0.76)$ o1 & & $-1.90( \pm 6.60)$ & 85.70 \\
\hline ユリカモメ & 29.67 & $0.07( \pm 0.03) \mathbf{w}$ & $+1.88( \pm 20.47)$ wfp & $-0.17( \pm 0.09) \mathbf{n} 1$ & & & & $5.64( \pm 4.30)$ & 100.70 \\
\hline シジュウカラ & 27.47 & $0.10( \pm 0.05) \mathbf{A}$ & $+0.11( \pm 0.05) \mathbf{r}$ & $+0.88( \pm 0.56) \mathbf{y} 1$ & & & & $-12.04( \pm 5.17)$ & 94.26 \\
\hline シロハラ & 2637 & $0.12( \pm 0.06) \mathbf{X}$ & $-0.08( \pm 0.04 \mathbf{r}$ & & & & & $-2.06( \pm 1.62)$ & 94.07 \\
\hline ショウビタキ & 12,09 & $0.01( \pm 0.04) \mathbf{b u}$ & $+0.26( \pm 0.18)$ wf & $-0.18( \pm 0.13) \mathbf{n} 1$ & $-0.09( \pm 0.10) \mathbf{w 3}$ & & & $8.50( \pm 6.96)$ & 72.67 \\
\hline マ更汑 & 12,09 & $0.02( \pm 0.05) \mathbf{r}$ & $+2.88( \pm 1.15) \mathbf{s}$ & $+0.29( \pm 0.19) \mathbf{w f}$ & $+0.22( \pm 0.14) \mathbf{n} 5$ & $-0.289( \pm 0.18) \mathbf{b u 4}$ & $-1.34( \pm 0.69) \mathbf{y} 2$ & $-9.80( \pm 13.90)$ & 61.23 \\
\hline ホシハジ口 & 12.09 & $0.19( \pm 0.05) \mathbf{w}$ & $-1.99( \pm 0.69) \mathbf{y} 2$ & & & & & $6.55( \pm 4.55)$ & 43.63 \\
\hline カルカ讬 & 12.09 & $0.28( \pm 0.10) \mathrm{g}$ & $-0.17( \pm 0.10)$ bu & $+2.30( \pm 1.58) \mathbf{s}$ & $-0.53( \pm 0.25) \mathbf{n} \mathbf{1}$ & $+7.02( \pm 2.90) \mathbf{y} 2$ & & $-49.11( \pm 23.09)$ & 40.50 \\
\hline
\end{tabular}


一方で，方形区内の舗装地の面積割合はハクセキレイやハシブ トガラス, シジュウカラの個体数やマガモの出現と有意な正の関 係性を示した。また，方形区内の建築物の面積割合はジョウビタ キの出現と有意な正の関係性を示し, $500 \mathrm{~m}$ 圈内の建築物の面積 割合はハシブトガラスの個体数と有意な正の関係性を示した。八 クセキレイは水辺で採食し5)，非舗装地や開放水域とも正の関係 性を示したことから，開放的な水辺への選好性が見受けられた。 ハシブトガラスは特に冬期に市街地一の選好性が高まり ${ }^{35)}$, 生ゴ

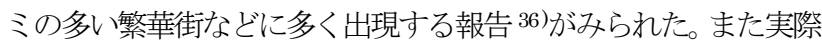
に集積されたゴミに群がる様子が調查中に確認され，ハシブトガ ラスは建築物が密集する大都市圏を利用している可能性が示唆さ

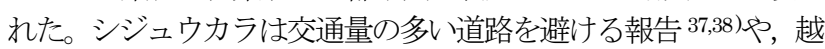
冬期に河川や都市への選好性が高まる報告 39)がみられた。今回設 定した調査地の方形区内は車が侵入できない遊歩道が大半であり， 特に大阪城公園付近の舗装地は広場のような開けた空間が多かっ た。そのため, 大阪城公園との近接性と併せて舗装地がシジュウ カラの出現と関係する変数として選ばれたと考えられた。水面採 食性のマガモは人や車などの人為攪乱を避けて休息する傾向にあ る報告 40)がみられた。水際線の長さや緩衝帯, 淀川への近接性も マガモの出現と正の関係性を示し，また淀川に近い空間の水際付 近は人が入れない護岸の空間が多かった。これらのことから，水 際から陸域方向一の延長線上にある舗装地は，マガモが休息する 空間として利用されている可能性が示唆された。ジョウビタキは 八ヶ岳周辺で定着・繁殖している個体がペンションなどの建築物 に営巣する報告 41 )がみられた。本研究では $100 \mathrm{~m}$ 圈内の緑被率や $300 \mathrm{~m}$ 圈内の開放水域の面積割合もジョウビタキの出現と負の関 係性を示しており，ジョウビタキは大都市圈の河川沿いの空間に おいて人工物を忌避しない傾向にあることが推察された。

\section{4. 結論}

大都市圏の河川における越冬期の鳥類に影響する環境要因を明 らかにすることで，今後集約化が進むであろう都市の生物多様性 向上に寄与する緑地計画の基礎的な知見を得た。

スズメやドバト，ヒヨドリ，ムクドリ，ツグミ，ハクセキレイ などの種は, 越冬期における大都市圈の河川を生息地として広く 利用していた。河川沿いの土地被覆や周辺の環境条件は各種の鳥 類の個体数に影響を示し，周辺緑地との近接性を加味した河川整 備の重要性が示唆された。周辺河川に近い空間に非舗装地を，樹 林地に近い空間に高木を中心とした植栽を計画することで, ツグ ミやシジュウカラの個体数が増加し，周辺河川や樹林地に近い空 間の水際部分に緩衝帯や湾曲を設けることで, オオバンやマガモ, カルガモなどの水鳥の個体数が増加することが見込まれた。多く の種が人工物を避ける傾向がみられた一方で，ハクセキレイや八 シブトガラス，ジョウビタキなど人工物の利用が示唆される種も 存在した。今後集約化が見込まれる都市の動態と鳥類の生息域の 変化に関して，更なる知見の蓄積が今後も必要だと考えられる。

本研究の結果から, 周辺の緑地と大都市圈をつなぐ河川周辺域 は, 都市の生物多様性を担保し得る空間だと考えられた。しかし， 今回は大都市圏の河川でのみ鳥類調査を実施したため, 大都市圏 の中で河川緑地が生物生息空間として担う相対的な役割はわから なかった。今後は大都市圈の河川のみならず周辺の緑地でも鳥類 調査と鳥類の出現に影響する要因の把握を実施することが課題と して考えられる。

謝辞：本研究は，株式会社パスコと京都府立大学との共同研究 (CM20171023)，「森林地域等における三次元空間情報解析技 術に関する高度化研究」の成果の一部です。関係各位に感謝申し 上げます。

\section{補注及び引用文献}

1 ) 環境省 (2012)：生物多様性国家戦略 2012-2020：環境省,252pp

2 ) 国立社会保障・人口問題研究所 (2017) : 日本の将来推計人口 (平成 29 年推計) : 国立社会保障・人口問題研究所, 58pp

3 ) 国土交通省 (2015) 国土形成計画 (全国計画) : 国土交通省, 173pp

4 ) 平野敏明・樋口広芳 (1988) : 冬季における川幅と水辺性鳥類の種数, 個体数との 関係 : Strix7，203-212

5 ) 平野敏明 (1997) : 河川改修が冬季における水辺性鳥類こおよぼす影響: Strix15, 39-44

6 ) Mason, C.F. , Hofmann, T.A. and Macdonald, S.M. (2006) : The winter bird community of river corridors in eastern England in relation to habitat variables : Ornis Fennica83, 73-85

7 ) 鈴木弘之 (2009): 河川における人為影響を含む景観要素が鳥類群集におよぼす影 響の解析一鳥類群集を指標として河川環境を保全するために一: 景観生態学 $13(1$ ・ 2), $55-69$

8 ) 高林裕・福井亘・宮本修詩・瀬古祥子 (2016) : 大阪市中之島における水際空間と 鳥類との関係 : 日本緑化工学会誌 42(1), 68-73

9 ) 小出舞・加藤和弘・渡辺達三 (2004) : 都市部河川緑地における越冬期の鳥類相に 影響を及ぼす要因 : ランドスケープ研究 67(5), 573-576

10）鈴木弘之 (2006) : 河川中流域における景観要素としての土地被覆の定性的簡易分 類と地形測量值に基づく夏季鳥類群集構造に影響をおよぼす要因の解析:景観生態 学 10(2), 89-99

11) Menon, M. , Devi, M. P. and Nandagopalan, V. (2015) : Species Diversity and Functional Assemblages of Bird Fauna Along the Riverine Habitats of Tiruchirappalli : India. Environmental Management of River Basin Ecosystems Part of the series Springer Earth System Sciences, 729-748

12) Suri, J. , Anderson, P.M. , Dominique, C. D. , Hellard, E. and Cumming G. S. (2016) : More than just a corridor: A suburban river catchment enhances birdfunctional diversity : Landscape and Urban Planning157, 331-342

13）樋口広芳・塚本洋三・花輪伸一・武田宗也（1982）森林面積と鳥の種数との関係 : Strix $1,70-78$

14）一八瀬友博・加藤和弘 (2003) : 都市域の小規模樹林地と都市公園における越冬期 の鳥類の分布に影響寸る要因 : ランドスケープ研究 66(5), 631-634

15) 加藤和弘 (1996) : 都市緑地内の樹林地における越冬期の鳥類と植生の構造の関係 ランドスケープ研究 59(5), 77-80

16）岡崎樹里・秋山幸也・加藤和引 (2006) : 都市緑地における樹林地の構造と鳥類の 利用について: ランドスケープ研究 69(5), 519-522

17) 葉山嘉一(1994) ; 都市緑地における鳥類の生息特性に関する研究:造園杂隹誌 $57(5)$ 229-234

18）宮本脩詩・福井亘（2014）：琵琶湖疏水およびその周辺環境条件と鳥類群集との 関係 : 日本緑化工学会誌 40(1), 108-113

19）宮本脩詩・福井亘 (2016) : 繁殖期の鳥類群集からみる都市部の線状緑地と周辺地 域との関係 : ランドスケープ研究 79(5), 703-706

20）森本豪・加藤和弘（2005）: 緑道による都市公園の連結が越冬期の鳥類分布に与え る影響: ランドスケープ研究 68(5)，589-592

21）橋本啓史・夏原由博・森本幸裕（2003）: 大阪市街地の都市緑地の樹林を利用する 鳥類を決定寸る要因 : 国際景観生態学会日本支部会報 8(3), 53-62

22) 黒沢令子 (1999) : 東京における鳥類相と環境要因としての舗装率:Strix13, 155-164

23）大阪市都市計画局企画振興部（2017）: 大阪市の概要，大阪市ホームページく http://www.city.osaka.lg.jp/toshikeikaku/page/0000402930.html>, 2017.6.13 更 新, 2017.9.9 参照

24）大阪府 $(2015)$ : 淀川水系西大阪ブロック河川整備計画 : 大阪府ホームページく http://www.pref.osaka.lg.jp/attach/4127/00011399/seibikeikaku (nishioosaka) .pdf>, 2015.4.13 更新, 2018.2.10参照

25）大阪市建設局公園緑化部調整課（2013）: 新・大阪市緑の基本計画 : 大阪市,84pp

26）加藤和弘・神山高義 (2014) : パッチ状樹林地の境界を越えて移動寸る鳥類の種組 成とパッチ外周の土地被覆との関係 : ランドスケープ研究 $77(5), 613-618$

27）鵜川健也・加藤和弘（2006）都市域の中・大規模樹林地における鳥類の種多様性 と立地環境との関係 : ランドスケープ研究 69(5), 533-536

28）一八瀬友博 (2006) 大阪市中心部の街路樹と越冬期の鳥類の出現状况の関係 : ラ ンドスケープ研究 69(5), 537-540

29） Bibby, C. J. ,Burgess, N. D. ,Hill, D. A. and Mastoe S. H. (2000） : Bird census techniques second edition : Academic Press, 91-112

30）楠頼雄三・福井亘・村上健太郎（2012）: 越冬期における大阪城公園の鳥類相と樹 林タイプとの関係: 名古屋産業大学論集(20), 1-13

31) 久保拓弥 (2012) : デー夕解析のための統計モデリング入門: 岩波書店, 143-167

32）加藤和弘・吉田亮一郎・高橋俊守・笠原里恵・一ノ瀬友博 (2015)）: 都市およひ 近郊の小規模樹林地で記録された鳥類の種組成に影響寸る要因:ランドスケープ研 究 78(5), 671-676

33) 加藤和弘・若山睦月 (2017) :千葉市西部の住宅地における鳥類相を規定する要因 : ランドスケープ研究 80(5), 723-726

34）叶内拓哉・安部直哉・上田秀雄 (2014) : 新版 日本の野鳥：山と渓谷社，671pp

35）藤田紀之・服部俊宏・東淳樹・尾上舞・矢澤正人・瀬川典久 (2015) : ハシブトガ ラスの行動巻特性の把握と個体数調整対策のための計画圏域の検討:農村計画学会 誌 $34(2), 160-166$

36）黑沢令子・成末雅恵・川内博・鈴木君子 (2000) : 東京におけるハシブトガラスと 生ゴミの関係: Strix18，71-78

37）橋本啓史・夏原由博（2002）: ロジスティック回帰をもちいた都市におけるシジュ ウカラの生息環境適合度モデル : ランドスケープ研究 65(5), 539-542

38) Fernandez-Juricic, E. (2000) : Avifaunal use of wooded streets in an urban landscape : Conservation Biology14, 513-521

39）百瀨浩・伊勢紀・橋本啓史・森本幸裕・藤原宣夫 (2004) 都市環境の広域的評価 の指標種としてのシジュウカラ生息分布予測モデル：ランドスケープ研究 67(5), 491-494

40) 鈴木弘之 (2009) : 河川における冬期の水鳥分布に影響を及ぼす自然要素と人為攪 乱: 日本鳥学会誌 $59(2), 174-180$

41）林正敏・山路公紀 (2014) : 八ヶ岳周辺におけるジョウビタキの繁殖と定着化 : 日 本鳥学会誌 63(2), 311-316 